\title{
Architectural Firms: Workforce, Business Strategy and Performance
}

\author{
Adedapo Adewunmi Oluwatayo, (Covenant University, Nigeria)
}

Dolapo Amole, (Obafemi Awolowo University, Ile-Ife, Osun State, Nigeria)

\begin{abstract}
The intent of this research was to investigate the relationship between the workforce, business strategy and performance of architectural firms. Data was collected from 92 firms randomly selected from the cities where architectural firms were most concentrated in Nigeria using questionnaires. Hierarchical regression analysis was carried out to investigate the direct and indirect impacts of the workforce of architectural firms on their performance. The findings confirm the significant positive impact. With business strategy controlled, the specific characteristics of the workforce and its management which influenced performance were the number of architects, the work structure, and the age and experience of the principal partners. The impact of the number of non- architecture professionals and staff participation in decisionmaking on performance was moderated by the business strategy adopted by the firms. The results suggest that workforce characteristics are more important than the management of the workforce in determining performance of architectural firms. This is contrary to the results of previous studies which suggest higher importance of the management. This probably indicates the peculiarity of architectural firm as a professional service firm in the construction industry.
\end{abstract}

Keywords: Workforce, Performance, Business strategy, Architectural firms, Professional service firms

\section{Introduction}

The architectural firm is the first choice of most newly-graduated architects. Sagada (2002), Schwennsen, (2004) and White (2005) however noted that architectural firms are not performing well. An explanation for this failure could be that the fate of the firm depends on the economy as a whole. Phua (2006) also noted that performance of firms depend on both industry- and firmspecific factors. The study by Hansen and Wernerfelt (1989) on the relative importance of economic and organizational factors in determining the performance of organizations concluded that while the economy determines the performance of industries and their structure, the unique attributes of a firm are important determinants of its performance relative to other firms within the same industry. An important issue in the research on the survival and success of firms is the resources and capabilities of the firm because their effects on the performance of firms (Bainey and Hesterly, 1999). The explanation given by Bainey and Hesterly (1999), for the heterogeneity of performance within a single industry builds on a variety of research traditions in organizational theory, which focus on the attributes of the firm and has come to be known as the Resource-Based View of the Firm a term first coined by Birger Wernerfelt in 1984.

Bharadwaj (2000) noted that proponents of the resource-based view generally tend to define resources broadly, to include assets, knowledge, capabilities, and organizational processes. Grant (1991) however differentiated between resources and capabilities noting that resources can be financial capital, physical assets, reputation, brand image, technology, and personnelbased resources (as training and expertise of individuals involved), while capabilities include functional and cross-functional capabilities which are rooted in processes and business 
routines. Several studies have investigated different resources and capabilities of the firms and how they affect the performances of those firms. These studies may however not represent the scenario in professional service firms whose primary assets are the highly educated workforce and whose outputs are intangible (Ettinger, 2009). In fact, the workforces of professional service firms are the critical assets because of the direct interaction of consultants with clients (Ettinger, 2009) and are thus a major source of competitive advantage (Rose and Kumar, 2006). Greenwood et al. (2005); in the attempt to explain the determinants of performance of professional service firms; also suggested that human capital is a professional service firm's most important resource. The implication of this as noted by Greenwood et al (2005) is that the loss of professionals (senior professional in particular) may hamper relationships with clients. Workforce, as used in this study is a composition of the knowledge, skill and experience of staff in an organization (Maister, 1993). It is sometimes defined as human capital or human resource as they are factors of production in organizations.

Scholars described the workforce as involving a mix of talents that are elusive and difficult to imitate (Richard, 2000). Richard further noted that human resources allow firms to succeed by giving them the skills needed to adapt products and services to market needs and meet competitive challenges. The resource-based view not only considers the resources but the context within which the resources are embedded (Oliver, 1997). Such contexts include the strategy, structure, and environment within which the resources are embedded. Ginsberg (1994) described strategy as an important context, with Wright McMahan and McWilliams (1993) asserting that the resource-based view emphasizes the link between the internal resources of the firm, its strategy and its performance. Scholars also argue that resources and strategy interact to produce positive returns (Hitt, et al, 2001). In addition, Hofer and Schendel(1978) suggested that at the business level, distinctive competencies and competitive advantages are the most important components of strategy in this regard.

This study is thus based on the notion that the workforce characteristics and management determine the performance of a firm and that this relationship is moderated by the strategies which the firm adopts. Although this idea has been investigated in many firms, it appears that it has not been examined in professional firms, especially architectural firms. Various studies on professional service firms had focused on accounting, law, and management consulting firms (Alvesson, 1995; Lowendahl, 2000). Blua (1984) however noted that the architectural profession is unique. Very little literature also exists on the workforce of architectural firms in developing countries and how they influence the performance of the firms. The few studies carried out on the workforce in developing countries include those for Sri-Lankan (Rameezdeen and Ramanchandra, 2008; and Ganesan, 1994); Vietnam (Luu, Kim, Cao and Park, 2008) and the Malaysian (Chan, 2009) construction industry. None of these studies have addressed the professional workforce of the architectural firms. In the light of the resolve of the government of Nigeria to diversify the economy of Nigeria, a report by Nathan Associates (2009) identified professional services as a viable measure. This is in the light of the increasing contribution of services to the Gross National Product of the Country. However, there is anecdotal evidence that architectural firms are not doing well. As noted earlier, the resource-based view identified resources, in this case the workforce, as means of building competitive advantage and improving profitability. Consequently, we examine the validity of this idea in the context of architectural firms in Nigeria. Our aim is to investigate the effect of the workforce as well as the interaction of the workforce with the strategy on the performance of architectural firms. We thus addressed four questions. First, to which extent do workforce characteristics and management directly affect performance of the firms. Second, which aspects of the workforce characteristics and management are the core competences which affect performance of the firms? Third, how does the strategy adopted by the firms influence their performance and fourth, what is the

Oluwatayo, A A and Amole, D (2011) 'Architectural firms: workforce, business strategy and performance', Australasian Journal of Construction Economics and Building, 11 (4) 21-44 
relationship between the characteristics and management of the workforce of the firms, their performances and the strategies they adopt?

We see this study as very valuable in three ways. First, we empirically identify the aspects of the workforce characteristics and management of the architectural firm which influence its performance. Second, we identify the strategies that are associated with higher performance and third, we empirically examine how the relationship between characteristics and management of the workforce of the firms and their performance is moderated by the strategy the firm adopts.

The resource- based view suggests that competitive advantage results from the link between resources, strategy and performance. This study thus argues that the workforce of an architectural firm is a resource, which influences the performance of architectural firms, moderated by the business strategies of the firms.

\section{Workforce of Architectural Firm as a Resource}

The resource-based view of the firm states that firms can develop sustained competitive advantage by creating value in a way that is rare and difficult for competitors to imitate (Wernerfelt, 1984). This view emphasizes the link between the internal resources of the firm, its strategy and performance. As noted earlier, Grant (1991) expanded resources of an organization from its original description as dynamic capabilities to include tangible, intangible and personnel-based resources. Acedo et al. (2006) noted that since the name was given to the resource-based view by Wernerfelt, in 1984, the approach has been extended to many fields including human resources (Lado and Wilson, 1994).

Greenwood et al (2005) defines professional service firm as those whose primary assets are a highly educated (professional) workforce and whose outputs are intangible services encoded with complex knowledge. The major resources of these firms are expertise, knowledge and experience of their professionals since they have very little physical resources (Maister, 1993). This is because, as Lowendahl (1997), noted the relationship with clients of professional service firms is interactive. This suggests that the firms are highly dependent on their workforce as they have to convince clients of their competencies, which is highly resident in their workforce. This makes it necessary for the professional service firms to attract and retain qualified personnel (Kärreman et al.2002) as they embody, operate and translate the knowledge which results in the firms' output. Malhotra, Morris and Hinings (2006) in their study of variations in organizational forms of accounting and law firms as well as Cliff et al. (2006) in their study of start-up law firms found that the dependency of the professional service firms on their workforce made them differ from other organizations. This is because while Cliff et al found organizational forms of professional service firms differ from those of other firms, based on their workforce; Malhotra et al. found an emergence of the P2 (professional partnership) archetype which they concluded is a response to market and institutional pressures. In addition, the workforce of the professional service firms is the basis of the firm's relationships. In view of the dependencies, Greenwood et al. (2005) in their study of the organizational determinants of performance found that workforce dependency influence the performance of professional service firms.

With the professional service firm like the architectural firm, personnel-based resources or the workforce are critical (Greenwood et al. 2005). Greenwood et al found that in addition to other factors, the reputation of professional service firms, which is dependent on the workforce of the firms, had significant influence on the performance of the firms. Workforce in this context is defined as the pool of human capital in direct employment relationship with the firms. This workforce has been described in literature as consisting of knowledge, skills and abilities of

Oluwatayo, A A and Amole, D (2011) 'Architectural firms: workforce, business strategy and performance', Australasian Journal of Construction Economics and Building, 11 (4) 21-44 
organizational members (Mckelvey, 1983). This is a further classification of Flamholtz and Lacey (1981) who simply defined the workforce as the skill of human beings in the organization. The workforce is described as a resource because it creates value for the firm, it is rare, inimitable, and non-substitutable (Wright, et al, 1993). With the architectural firm, the workforce includes both the staff and the owner(s), or principal(s), who is often directly involved in the dayto-day tasks of the firms. This is particularly so for the architecture firm because the firms are always hired for their expertise and skills which enables them to produce an outcome that the client can use (Jones et al.1998). This expertise and skill reside in the workforce because the professional generates the talents and capabilities required for the services offered by the firms. In particular, tasks in the architecture firm involve individual expertise used to solve client's problems.

Brown et al. (2010) described architectural firms as creative organizations in which skilled professional turn imaginative ideas into disciplined practices and practices into profit. This probably highlights the importance of the workforce in architectural firms with Brown et al further noting that firms of architects rely on the expertise of their staff in order to trade sell a capacity to produce. This goes further to confirm the statement by Winch and Schneider (1993) that the assets of an architectural practice are its people. Jones and Lichtenstein (2000) also asserted that design is the architectural firm's preeminent skill and this is resident in the workforce of the firms. With the architectural firm as a professional service firm however, an important principle is that the client always comes first, necessitating closer owner-client personal relationship. For this reason, professional service firms are generally privately owned (Maister 1993). The implication is that the owner/ principal of an architectural firm is mostly a part of the workforce.

These characteristics set the architectural firm apart and suggest the need to study the relationship between workforce, strategy and performance in the context of architectural firms as they cannot be assumed to be like other professional service firms. Dewan and Kraemer (2000) in their studies in developing countries suggested that cultural, socio-economic and regulatory environment may be responsible for differences in findings on Information Technology (IT) in organizations between developed and developing countries. In fact, Austin (1990) noted that results of management of organizations in developed economies may not be applicable to a developing country like Nigeria for these reasons. This study thus attempts to investigate the relationship between workforce, strategy and performance of architectural firms in the context of a developing country (in this study, Nigeria) to provide the true picture of workforce, strategy and performance in a typical developing country. This may define the limits of generalization of previous studies.

Within the construction firm, Ness (2010) also conceptualized people as an asset, noting that they a means to an end in terms of their contribution to the profitability of the firm. Different aspects of the workforce have been studied in the construction industry. These include employee participation (Coffey and Langford, 1998); characteristics of owners, (Kim and Arditi 2010; Fraser, 2000); employment mode (Druker and Croucher, 2000; Jayawardane and Gunawardena, 1998); and employee project deployment practices (Raiden et al. 2008). Lu and Sexton (2006) also investigated that the human capital of small construction knowledgeintensive professional service firms as embodiment of their capability to innovate.

Wright and McMahan (1992) further in their theoretical paper suggested that the larger human capital pool determines the organization's success. These authors suggest that the workforce would be more likely to have impact on performance. Researchers like Reich (1991); and Ulrich and Lake (1990) have also argued that traditional sources of competitive advantage related to

Oluwatayo, A A and Amole, D (2011) 'Architectural firms: workforce, business strategy and performance', Australasian Journal of Construction Economics and Building, 11 (4) 21-44 
markets, financial capital, and scale economies have been weakened by globalization. Thus, the workforce may be the ultimate influence on the performance of the firm.

\section{Workforce Resource and Performance of Firms}

There have been several studies linking the characteristics of the workforce as a resource to firm performance. Many of these studies have been based on the resource-based view of organizational studies. Using this view, studies have focused on workforce characteristics or workforce management. Some characteristics of the workforce were found to influence the performance of firms in previous studies. For example, Hitts et al (2001) investigated human capital in terms of the number, quality of education and total experience of the partners. They found that the effect of human capital on performance is fist negative, but turns positive with higher levels of human capital. The study of professional service firm performance by Greenwood et al (2005) however revealed a negative correlation between number of professionals and the performance of the firms. Another characteristics of the workforce investigated in literature is gender, which was also found to influence performance of firms in a research on racial diversity by Richard (2000). Richard however found that the impact of diversity on performance had to do with context and was not in any way direct. Daily, Certo and Dalton (2000) also assert that managers of organizations are a unique organization resource. The characteristics of the managers that have been suggested to influence performance include education, and experience (Hitt et al 2001; and Pennings et al. 1998). With the architectural firm as a professional service firm, the partners are the most important resource. Hitt et al, (2001) explained why this is so. They noted that relationships with current and potential clients and hence social capital of the firms are built by the partners. In addition, partners in a firm have the largest stakes in using the firm's resources to the greatest advantage. In fact, Li et al. (2009) in their study of competency factors in real estate firms found that management competences contribute to competitiveness. This suggests the need to study the characteristics of the principals such as their experiences and education, which may determine their efficiency in task performance and thus the performance of architectural firms.

Some studies have been carried out on the effect of workforce on performance of firms in the construction industry. Examples include the study by Fraser (2000) and Kim and Arditi (2010) which focused on the effect of the characteristics of owners of construction firms on performance. Characteristics of the owners of construction firms which have been found to influence performance are educational level, involvement in continuing education, number of firms worked for, membership of professional bodies and leadership style (Fraser, 2000). Very few studies in the construction industry and particularly architectural firms have however linked the entire professional workforce to the performance of the firms.

The afore-mentioned studies focused on workforce characteristics. However, several researchers concluded that it is the management of human capital, rather than the physical capital that is the most important determination of firm performance (Patterson et al. 1998). These human resource practices are defined as the organizational activities carried out to manage the workforce. A significant aspect of the firm's resources has been the human resources management practices. Previous researchers found a positive relationship between human resource management practices strategy and performance (Rose and Kumar, 2006; Huselid, 1995). The works of Kleiner et al. (1987); Russell et al. (1985); Terpstra and Rozell (1993); U.S. Department of Labor (1993) for example, provided empirical evidence that human resource practices directly influence performance. Human resource practices that were found to influence performance of organizations include staff selection standards (Ichniowski et al. 1993; MacDuffie, 1995); staffing techniques (Huselid, 1995); rewards and incentives (MacDuffie, 1995; Youndt et al. 1996) and employee participation in decision-making (Arthur, 1994; Ichniowski et

Oluwatayo, A A and Amole, D (2011) 'Architectural firms: workforce, business strategy and performance', Australasian Journal of Construction Economics and Building, 11 (4) 21-44 
al, 1993) and job specialization (Ichniowski et al, 1993). Human resource practices in this study is thus defined in terms of the criteria for staff selection, mode of staffing, means of compensation, task specialization and level of employee participation in decision-making. Arthur (1992, 1994) carried out his study in manufacturing organizations. He found that human resource practices which focused on enhancing employee commitment (e.g., decentralized decision making, comprehensive training, salaried compensation, employee participation) were related to higher performance. He found however, that human resource practices that focused on control, efficiency, and the reduction of employee skills and discretion were associated with increased staff turnover and poorer performance. The finding of Huselid (1995) was similar. In the empirical study of human resources Huselid found that investments in Human Resource (HR) activities such as incentive compensation, selective staffing techniques, and employee participation resulted in lower turnover, greater productivity, and increased organizational performance through their impact on employee skill development and motivation. For the architectural firm, Larsen (2005) also noted that personnel management is a criterion differentiating successful architectural firms from their less successful counterpart.

Workforce characteristics in this paper is thus defined in terms of the number, qualifications, designation, and gender of staff as well as the age, gender, education, registration with professional body, leadership style and experience of the principal. This paper builds on previous studies by investigating these workforce characteristics, including characteristics of firm's principals in addition to human resource practices of architectural firms. Carton and Hofer (2006) defined performance as a contextual concept associated with the phenomenon being studied. They further argued that measures used to represent performance are selected based upon the circumstances of the organization being observed. The dimensions of performance measured in literature include efficiency, growth, profit, size, liquidity; success, market share, and leverage. This study defines the performance of the architectural firms in terms of their profitability.

\section{Workforce, Business Strategy and the Performance of Firms}

The resource- based view of the firm emphasizes the link between the internal resources of the firm, its strategy and its performance (Wright et al 1993). This is one important context that researchers agreed should be considered when studying resources of a firm using the resourcebased view (Miller and Shamsie, 1996; Ginsberg, 1994). In fact, an important aspect of the definition of resources given by Barney (1991) is that they enable the firm to conceive and implement strategies that improve efficiency and effectiveness (Schoenecker and Cooper 1998). This suggests that strategy may interact with workforce as a resource to influence performance. Hofer et al (1978) opined that at the business level, distinctive competencies and competitive advantages are the most important components of strategy. Business-level strategy constitutes one factor that warrants consideration. The study by Cheah et al. (2007) focusing on large construction firms found that the strategies which directly influence revenue and profit growth are market and product differentiation, which are related to the business strategy that a firms adopt. A similar study by Houthoofd (2009) found that performance of firms varied with the construction market served. The business level strategy that we seek to address is defined in terms of the actions taken by firms to select market and generate new jobs (Wang and Yang 2000). These include the means of building clientele, the client types; the project types handled and criteria for project selection.

Various classifications of the business strategies exist (Miles and Snow 1978; Sherer 1995, Lowendahl, 2000 and Greenwood, et al, 2005). Researchers have found a relationship between the previous strategy types and performance of firms. Using the strategy types derives by Miles and Snow (1978), Conant, et al (1990) studies Health Maintenance Organizations and

Oluwatayo, A A and Amole, D (2011) 'Architectural firms: workforce, business strategy and performance', Australasian Journal of Construction Economics and Building, 11 (4) 21-44 
found that defenders, prospectors and analyzers performed equally well and outperformed reactors. Building on the works of Conant et al. (1993) studied catalogue and mail order houses and found a similar result, although in their study, prospectors were best performers, followed by analyzers. With the professional service firm, Becker et al. (2001) in a study of international law firms found that the more profitable firms were those with narrow specialization strategies as against firms with a diversification strategy. This agreed with the findings of David (2001) that specialization reduced the failure of consulting firms. These researchers concluded that appropriate implementation of business strategy result in better performance. Lee and Miller (1999) in their study of employee commitment also asserted that human capital is a vital resource in the implementation of strategy, which further influence performance. This assertion have been confirmed in the works of scholars like Youndt et al (1996) who found a moderating effect of manufacturing strategy on the influence of human resource management on manufacturing firm performance. Greenwood et al (2005) in the study of determinants of performance of professional service firms and Hitt et al (2001) in their study of human resources, strategy and performance also confirmed the moderating effect of human the workforce on the relationship between diversification strategy and performance of law firms. Very few studies have however investigated this assertion in the context of architectural firms. It is in this context that we examine the relationship between the business strategy adopted by architectural firms as firms in the construction industry and their performance. We also examine the interactions of workforce characteristics and strategy types which influence the performance of the firms.

For the construction industry, Katsanis and Katsanis (2001) identified the following business strategies: the prestige, selective (specialization), sustenance and harvester strategies. These strategies were based on the project type, criteria for project selection, client types and means of building clients (Table 1). The selective strategy nurture and develop expertise in a specific area, while the harvester strategy "explore and pursue" in order to remain abreast of market developments. The prestige strategy aim at high-profile projects, while the sustenance strategy lacks a coherent strategy. The relationship between these strategies and the performance of firms in the construction industry, especially architectural firms has however received little empirical support. These strategies are investigated in this study.

\begin{tabular}{|c|c|c|c|c|}
\hline & Harvester & Selective & Prestige & Sustenance \\
\hline Project Type & $\begin{array}{l}\text { Determined by } \\
\text { recent trends }\end{array}$ & $\begin{array}{l}\text { Specialized } \\
\text { projects }\end{array}$ & High profile & Broad category \\
\hline $\begin{array}{l}\text { Means of building } \\
\text { clientele }\end{array}$ & Public relations & $\begin{array}{c}\text { Other } \\
\text { professionals }\end{array}$ & $\begin{array}{l}\text { Brand name/ } \\
\text { past projects }\end{array}$ & $\begin{array}{l}\text { Personal relation- } \\
\text { ships/ Request For } \\
\text { Projects (RFP) }\end{array}$ \\
\hline Client types & $\begin{array}{l}\text { Determined by } \\
\text { prevailing } \\
\text { conditions }\end{array}$ & Specialized & & Diverse \\
\hline $\begin{array}{l}\text { Criteria for project } \\
\text { selection }\end{array}$ & $\begin{array}{c}\text { Booming project } \\
\text { type Determined } \\
\text { by govern-ment } \\
\text { legislations }\end{array}$ & Expertise & $\begin{array}{l}\text { Technical } \\
\text { complexity/ } \\
\text { aesthetic } \\
\text { potential }\end{array}$ & Availability \\
\hline
\end{tabular}

Table 1 Characteristics of strategy types derived by Katsanis and Katsanis (2001)

Source: Adapted from Katsanis and Katsanis (2001)

Oluwatayo, A A and Amole, D (2011) 'Architectural firms: workforce, business strategy and performance', Australasian Journal of Construction Economics and Building, 11 (4) 21-44 


\section{Conceptual Framework}

Often, professional service firms are faced with the task of selecting market segments and generating new jobs (Wang and Yang, 2000). This is important if the firm is to remain profitable. The architectural firm in particular selects such markets and jobs based on the availability of relevant manpower. This is because different markets and jobs pose different challenges and opportunities. The conceptual framework adopted by this study, as presented in Figure 1, proposes that workforce influence profitability performance and that this impact is moderated by a firm's business strategy.

As mentioned earlier, the workforce of a professional service firm, like the architecture firm, is a vital resource which contributes to the competitive advantage of the firm. In addition, workforce as a resource facilitates the implementation of strategies (Hitt et al, 2001).

Figure I suggest a direct influence of the workforce on the performance of the firms. The study suggests that business strategy may influence performance directly, and in addition interact with workforce to further influence performance.

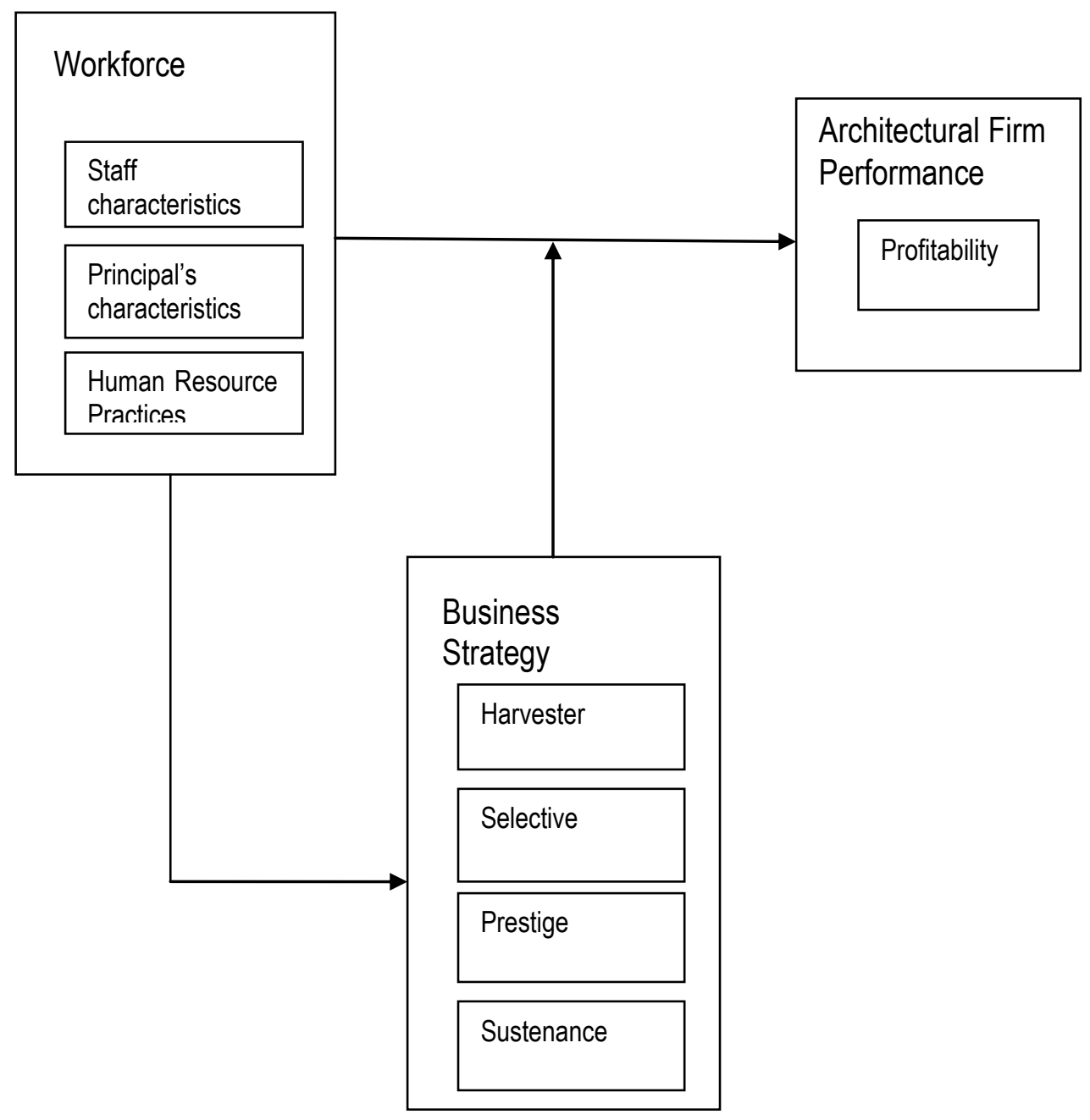

Figure 1 Workforce, business strategy and performance

Oluwatayo, A A and Amole, D (2011) 'Architectural firms: workforce, business strategy and performance', Australasian Journal of Construction Economics and Building, 11 (4) 21-44 


\section{Method \\ Data Collection Instrument}

The aim of this study is to investigate the effect of the workforce as well as the interaction of the workforce and strategy on the performance of architectural firms. We therefore designed a close-ended self- administered questionnaire for data collection. We administered the questionnaire personally and with the help of research assistants, after unsuccessful attempts at using electronic mails. The chosen informants in each firm were individuals intimately involved in the operation of the specific firms; in most cases the principal, partners, or senior associates as in recent studies by Hitt et al (2001) and Brock et al (2006). The firms were chosen from the list of Architectural firms that were registered to practice in Nigeria (ARCON, 2006). These firms were core architectural firms which in some cases have other building industry professionals as employees. They were however not registered with the Architects Registration Council of Nigeria as consortiums. In the first section of the questionnaire, we gathered information on the characteristics of the firms such as size, employee and principal characteristics, and perception of firm's performance in terms of profit. In the second section we gathered information on the actions taken by firms to select market and generate new jobs which constitute business strategy. We initially conducted a pilot test of five architectural firms to improve the questionnaire.

\section{Measurements}

The works of Richard (2000) on racial diversity, business and performance used the gender of the workforce as control variable. Similarly, Youndt et al (1996) in a study of workforce management, strategy and performance used the size of the workforce as control variable. These researchers attempted to isolate the effects of these characteristics because they were believed to influence performance. We however investigate the direct influence of workforce characteristics on the performance of architectural firms. The workforce characteristics variables which we used in the questionnaire were the number, gender qualifications and designation of professionals (Hitt et al, 2001); while the human resource management strategies examined were the staff selection criteria, staffing techniques, rewards and incentives, employee participation in decision making and job specialization as earlier discussed. Business strategy type was measured using the responses of the principals to questions on their client types, means of attracting clients, project type as well as criteria for project selection taking a cue from the work of Katsanis and Katsanis (2001). Data on profitability was not available in the architectural firms. Tax returns would have shown this but data on tax returns were not reliable. Information on assets, revenues, investments, market share, actual profit, and other accounting measures were only known to the principals who were reluctant to divulge such information. We were also not able to access the audited accounts of the firms. However, the principals were willing to indicate their perception of profit on a scale. Dess, and Robinson (1984) also confirmed that objective measures of performance are often not available in privately-held firms, noting that subjective measures, obtained from top management teams are often used. In fact Wall et al. (2004) found that such measures are as valid as the objective measures. We therefore operationalized the performance of the firms as perception of the firms on the profit made in the previous year since we had to depend on the memory of the principals (Carton and Hofer, 2006).

\section{Sample of the Study}

The sampling frame comprised architectural firms registered with the Architects Registration Council of Nigeria (ARCON, 2006). We used random sampling methods to select the firms in the study, which was the unit of data collection and analysis. We adopted the mode of determination of sample size for a finite population developed by Frankfort-Nachimias and

Oluwatayo, A A and Amole, D (2011) 'Architectural firms: workforce, business strategy and performance', Australasian Journal of Construction Economics and Building, 11 (4) 21-44 
Nachimias (1992). In this study, we determined how large the sample of architectural firms was assuming $95 \%$ confidence that the probable error of using a sample rather than surveying the whole population did not exceed 0.05 . With a population of 341 registered architectural firms, the calculation gave a sample size of 157, which were sampled. The questionnaires were administered between February and May 2008. A total of 92 questionnaires were returned duly completed, giving a response rate of $59 \%$. The sample size was similar to those in previous studies (Hitt et al, 2000; Brock et al, 2006)

\section{Analysis}

First, we reduced the workforce and human resource management variables using the Principal Component method of analysis. This was carried out to assess the convergence and divergence among the workforce and human resource management variables in order to determine the underlying dimensions. This reduced the variables into non correlated variables as can be seen in Table 2. Second, to identify groups of architectural firms which had some degree of commonality among strategic views, we carried out a two-step cluster analysis (Arthur, 1994) followed by analysis of variance to determine the differences between clusters. The different types of strategy and their distinguishing features were thus identified. Third, as in similar studies (Youndt et al, 1996; Richard, 2000; Hitt et al, 2001) we carried out hierarchical regression analysis in order to isolate the main effects of the workforce characteristics and human resource management systems on performance and to independently assess how the business strategy adopted by the firms moderated the relationship between workforce and performance. With the hierarchical regression, the direct effect of business strategy was first measured, and then the direct effect of the workforce, before the interaction effect of the workforce and strategy was measured.

\section{Results}

In this section we present the results of the study. The result of the principal component analysis is first presented, followed by the results of the cluster analysis. This clearly defines the workforce factors and the business strategy types which are further investigated in relation to the performance of the firms. The principal component analysis revealed that some of the variables of workforce and human resource management converged; revealing five underlying dimensions (Appendixes 1 and 2). These were the architects and work structure; the number of professional employees that were not architects (such as builders, quantity surveyors and engineers); staff participation in decision making; skill flexibility; and age and experience of principal.

To identify the strategy types adopted by the architecture firms, we carried out two-step cluster analysis, using the log-likelihood distances between groups, to identify groups of architectural firms that shared some degree of commonality among strategic views. The confidence level was set at 95\%. A 4- clusters solution was obtained. Of the 92 cases, $33(36 \%)$ firms were assigned to the first cluster, $30(32 \%)$ firms to the second cluster, $19(21 \%)$ firms to the third cluster, and $10(11 \%)$ firms to the fourth. The discriminant analysis classification reveals that $82 \%$ of the firms were determined to be correctly classified through cluster analysis. This suggests that the four cluster solution was internally valid, thus supporting the resulting taxonomy of architectural firms based on their business strategy.

We found significant differences among the clusters for some variable, using analysis of variance. The variables which differentiated the clusters were target of local clients (individual and organization); business development through family and friends, public relation strategies, other professionals and previous projects; and variances of projects in the firm's portfolio. The first cluster of firms consisted of firms that do not appear to have specialized in any project type.

Oluwatayo, A A and Amole, D (2011) 'Architectural firms: workforce, business strategy and performance', Australasian Journal of Construction Economics and Building, 11 (4) 21-44 
The cluster was further characterized by the strongest tendency to build clientele through family and friends and was similar to the sustenance strategy of Kastanis and Kastanis (2001). The second cluster, characterized by the highest number of educational, transportation, healthcare, civic and hospitality projects as well as the highest tendency to build clientele by public relations, resembled the harvester strategy. These projects are capital intensive projects, the availability of which may have been influenced by the recent focus of the government of Nigeria on the development of these sectors of the economy. Resembling the selective strategy, the third cluster obtained was characterized by apparent specialization in commercial projects and the least interest in other project types. The last cluster was characterized by focus on hospitality, religious and healthcare projects. These types of projects have high aesthetics potentials; thus this cluster could be seen as resembling the prestige strategy of Kastanis and Kastanis.

Analysis of variance was carried out to examine the influence of the business strategy adopted by the firms on the performance of the firms. The results show that there were significant mean differences in business strategy in relation to the performance of the firms $(F=2.810, p<0.05)$. The proportion of variance in performance accounted for by the business strategies was $1.4 \%$. The post hoc multiple comparison showed that the firms adopting the selective strategy were more profitable than firms adopting sustenance (mean difference $=0.31$, standard error $=0.13$, $\mathrm{p}<0.05$ ); harvester (mean difference $=0.095$, s.e $=0.13, \mathrm{p}<0.05$ ); and prestige (mean difference $=0.34$, s.e $=0.18, p<0.05$ ) strategies. The result also show firms adopting the harvester strategy performed better than those adopting the sustenance (mean difference $=$ 0.22 , s.e $=0.11, p<0.05$ ) and prestige (mean difference $=0.24$, s.e $=0.17, p<0.05$ ). In addition, the firms adopting the prestige (mean difference $=0.03$, s.e $=0.17, p<0.05$ ) strategy were outperformed by the firms adopting the sustenance strategy. This suggests that the highest performers were firms that adopted the selective strategy while the least performers were the firms that adopted the prestige strategy (figure 2).

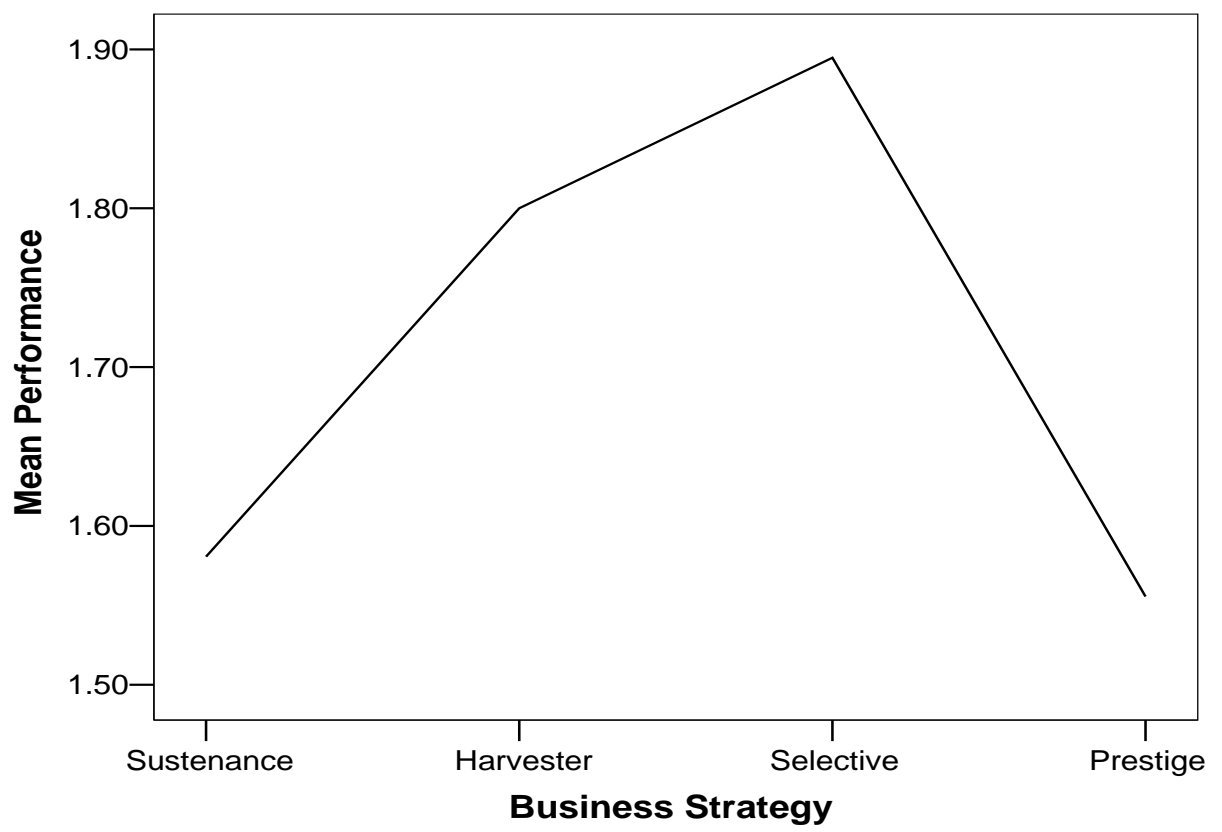

Figure 2 Strategy and performance

Oluwatayo, A A and Amole, D (2011) 'Architectural firms: workforce, business strategy and performance', Australasian Journal of Construction Economics and Building, 11 (4) 21-44 
The correlation of the variables in the study is presented in Table 2. Hierarchical regression analysis was used to investigate the relationship between workforce, strategy and performance of the firms, in line with the work of Richard (2000). Business strategy variables were entered first to control for any effect that business strategy may have on workforce characteristics and human resource management. A direct relationship will be indicated by significant effects. The workforce characteristics and human resource management was entered second to test direct association between workforce characteristic and managements, and the performance of the firms. This also eliminated the main effect of workforce prior to examining potential business strategy/ workforce interaction effects. The interaction between workforce and strategy was entered in the third step. Significant effect here would indicate that the relationship between workforce and performance is moderated by the business strategy. Table 3 displays the results of the hierarchical regression analysis for performance. The results show that with the business strategy controlled, the workforce was significantly related to performance (R2 change, $=0.277$, $p<0.01$ ), accounting for $28 \%$ of the variance in performance of the firms. Specifically, architects and work structure (Wald =8.697, $p=0.003$ ); and age and experience of principal (Wald =4.030, $p=0.045)$ significantly influenced performance. In addition, the workforce- business strategy interaction accounted for significant incremental variance (R2 change $=0.091, p<0.05$ ), resulting in a further $9 \%$ differences in performance. This result suggests that business strategy does in fact moderate the workforce-performance relationship. Business strategy interacted through the number of non architecture professionals (Wald $=-6.028, p=0.014$ ) and staff participation in decision making (Wald $=-2.501, p=0.077$ ) to influence performance.

\begin{tabular}{|c|c|c|c|c|c|c|}
\hline & $\begin{array}{l}\text { Perception } \\
\text { of Success }\end{array}$ & $\begin{array}{l}\text { architects } \\
\text { and work } \\
\text { structure }\end{array}$ & $\begin{array}{l}\text { number of non- } \\
\text { architecture } \\
\text { professionals }\end{array}$ & $\begin{array}{c}\text { staff } \\
\text { participation } \\
\text { in decision } \\
\text { making }\end{array}$ & $\begin{array}{c}\text { skill } \\
\text { flexibility }\end{array}$ & $\begin{array}{l}\text { age and } \\
\text { experience } \\
\text { of principal }\end{array}$ \\
\hline Performance & 1 & & & & & \\
\hline $\begin{array}{l}\text { Architects and } \\
\text { work structure }\end{array}$ & $.24\left({ }^{* *}\right)$ & 1 & & & & \\
\hline $\begin{array}{l}\text { Number of non- } \\
\text { architecture } \\
\text { professionals }\end{array}$ & -.16 & 0 & 1 & & & \\
\hline $\begin{array}{l}\text { Staff } \\
\text { participation in } \\
\text { decision } \\
\text { making }\end{array}$ & $.22\left(^{\star}\right)$ & 0 & 0 & 1 & & \\
\hline Skill flexibility & -.13 & 0 & 0 & 0 & 1 & \\
\hline $\begin{array}{l}\text { Age and } \\
\text { experience of } \\
\text { principal }\end{array}$ & .19 & 0 & 0 & 0 & 0 & 1 \\
\hline
\end{tabular}

Table 2 Correlations

${ }^{* *}$ Correlation is significant at the 0.01 level (2-tailed), ${ }^{*}$ Correlation is significant at the 0.05 level (2-tailed)

Figure 3 shows all high performers except those adopting the sustenance strategy had lower number of non-architecture professionals than their low performing counterparts. However, all high performers except those adopting the harvester strategies exhibited higher staff participation in decision making than their low performing counterparts. This probably suggest that adoption of the sustenance strategy coupled with high number of non-architecture professionals resulted in high performance while staff participation in decision making coupled with the prestige, selective or sustenance strategy also resulted in higher performance. The results further suggest that proper alignment of workforce with business strategy results in maximum performance of architectural firms. 


\begin{tabular}{|c|c|c|c|c|}
\hline \multirow{2}{*}{\multicolumn{2}{|c|}{ Variables }} & \multirow{2}{*}{\multicolumn{3}{|c|}{$\begin{array}{c}\text { Performance } \\
\text { b }\end{array}$}} \\
\hline & & & & \\
\hline & & \multirow{2}{*}{$\begin{array}{l}\text { step } 1 \\
1.252\end{array}$} & \multirow{2}{*}{$\begin{array}{l}\text { step } 2 \\
1.328\end{array}$} & \multirow{2}{*}{$\begin{array}{l}\text { step } 3 \\
0.406\end{array}$} \\
\hline $\begin{array}{l}\text { business } \\
\text { strategy }\end{array}$ & business strategy & & & \\
\hline \multirow[t]{5}{*}{ Workforce } & architects and work structure & & $8.697^{\star *}$ & 3.580 \\
\hline & number of non-architecture professionals & & 0.411 & $4.806^{*}$ \\
\hline & staff participation in decision making & & 1.812 & $4.198^{*}$ \\
\hline & skill flexibility & & 2.518 & 0.002 \\
\hline & age and experience of principal & & $4.030^{*}$ & 0.280 \\
\hline \multirow{7}{*}{$\begin{array}{l}\text { Strategy/ } \\
\text { workforce } \\
\text { interaction }\end{array}$} & business strategy $\mathrm{x}$ architects and work structure & & & 0.094 \\
\hline & $\begin{array}{l}\text { business strategy } x \text { number of non-architecture } \\
\text { professionals }\end{array}$ & & & $6.028^{*}$ \\
\hline & $\begin{array}{l}\text { business strategy } x \text { staff participation in decision } \\
\text { making }\end{array}$ & & & $3.125^{+}$ \\
\hline & business strategy $x$ skill flexibility & & & 0.546 \\
\hline & business strategy $x$ age and experience of principal & & & 0.229 \\
\hline & $\mathrm{R} 2$ change & & $0.277^{* *}$ & $0.091^{*}$ \\
\hline & $\mathrm{R} 2$ & 0.015 & $0.292^{\star *}$ & $0.383^{*}$ \\
\hline
\end{tabular}

Table 3 Results of simultaneous hierarchical regression analysis for performance

${ }^{*} p<.05$, two-tailed test, ${ }^{* *} p<.01$, two-tailed test, $+p<.10$, two-tailed test

\section{Discussion}

The purpose of this study was to deepen insight into the relationship between workforce of the architectural firm as a professional service firm and the performance of the firm. The study confirms the assertion of Ness (2010) that people are an asset in an organization. The results reveal the workforce characteristics which influence the performance of architectural firms as well as the dimensions of workforce characteristics that interact with strategy to further influence performance. A positive relationship between workforce and the performance of the firms was observed as in previous literature (Richard, 2000; Hitt et al, 2001). This supports the resourcebased view which notes that the workforce is a resource of an organization and support recent arguments by these scholars on the importance of the workforce to the performance of firms. It is amazing that even with the business strategy controlled, workforce accounted for a notable $27.7 \%$ of the variance in performance of architectural firms. This is high compared with the 3.6\% variance found in the study of workforce of large law firms by Hitt et al (2001) and 3.8\% variance in the study of workforce management of manufacturing firms by Youndt et al (1996). This suggests that the workforce is an area to watch if the architectural firm is to remain profitable. The study confirms that expertise of a firm in the construction industry is essential to its success (Xia, Chan, and Yeung, 2009). As mentioned earlier, this expertise resides in the workforce in the case of the architectural firm. It is interesting to note that although Patterson et al (1998) asserted that the management of the workforce was the most important determinant of firm performance, none of the workforce management practices had direct influence of the performance of architectural firms. Only workforce characteristics had direct influence of the performance of the firms. The workforce characteristics that accounted for the $27.7 \%$ variance in performance were the architects (number, qualifications, designation, professional registration and gender) and the age and experience of principal partners.

Oluwatayo, A A and Amole, D (2011) 'Architectural firms: workforce, business strategy and performance', Australasian Journal of Construction Economics and Building, 11 (4) 21-44 
Contrary to the findings of Brock et al (2006), the number of professionals (in this case, architects) is a significant determinant of performance. The results suggest that firms with more architects with higher qualifications and placed on higher designations perform better. This is contrary to the findings of Greenwood et al (2005) which found that larger professional service firms were poor performers. This probably confirms that architectural firms are different from other professional service firms.
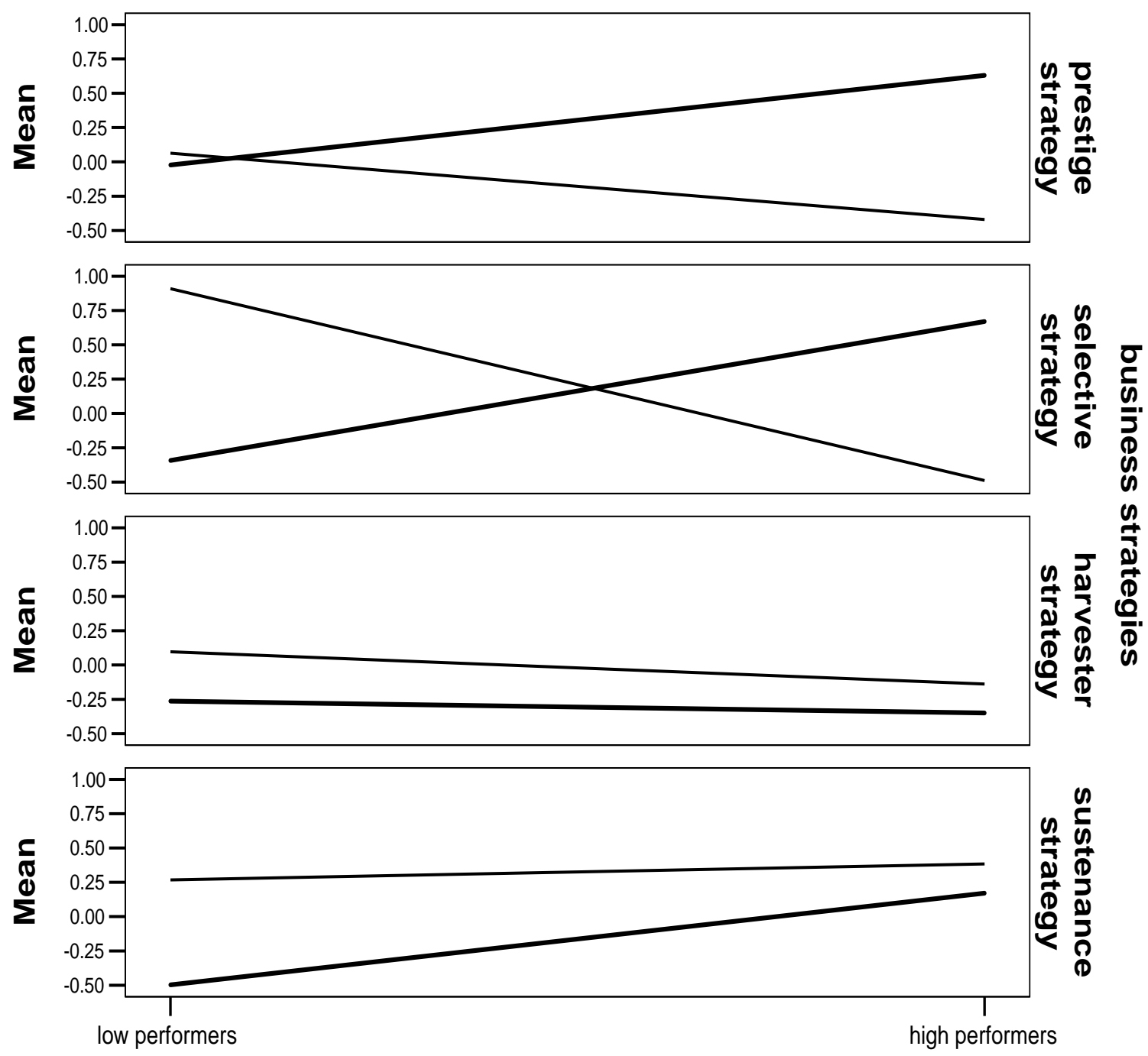

performance

$\longrightarrow$ taff participation in decision making
number of other professionals

Figure 3 Interaction results

Oluwatayo, A A and Amole, D (2011) 'Architectural firms: workforce, business strategy and performance', Australasian Journal of Construction Economics and Building, 11 (4) 21-44 
The results also confirm the findings of Hitt et al (2001) and Fraser (2000) that the experience of partners positively influence performance. Contrary to the findings of Fraser (2000) however, the education level of the principal partners did not influence the performance of the firms, although the education level of the staff mattered. Similarly, the leadership style of the principal partners did not influence the performance of the architectural firms. In addition however, the work structure of the firm and the ages of the principals were significant determinants of the performance of the firms. The results also suggest that firms with task specialization as well as experienced principals performed better. This probably implies that professional service firms seeking to improve performance should pay attention to the skilled professionals within the firms as well as their job design (Arthur, 1994).

Business strategy was also found to influence the performance of the firm, although the level of direct influence was low. The results confirm the findings of Li et al (2009) that market coverage is indeed essential to the performance of firms in the construction industry. The findings suggests that the selective strategy, probably due to its narrow focus which only necessitates the improvement of efficiency of existing operations (Kastanis, 2001) outperformed the three other business strategy types. This confirms the results of David (2001) and Becker et al (2001) who found that professional service firms with narrow focus were best performers. It is not clear why the selective strategy outperformed the harvester strategy, which handled projects which were mostly carried out by the government including educational, transportation, health, civil, and hospitality projects and would have been expected to be best performers in line with the findings of Houthoofd (2009). An explanation for the firms adopting the harvester strategy coming next to those with the selective strategy in performance may be that firms with the harvester strategy strive for early entrance into new market segments, exposing them to risks they may be unprepared for. In addition firms with the harvester strategy probably outperform those with the sustenance and prestige strategies because they pursue the most active market segment. The sustenance strategy also probably outperformed the prestige strategy because they accepted jobs as they come to keep the firm busy as against specific project stance taken by the firms with prestige strategy irrespective of the availability of such project.

The result suggest that the impact of the workforce on the performance of the firms is both direct and indirect, confirming the work of Hitt et al (2001). This is because our findings on the interaction of strategy with workforce characteristics to influence performance show that the two workforce characteristics which interacted with strategy to further influence performance were the number of other professionals and staff participation in decision-making. Although Coffey and Langford (1998) found a significant potential for participation in the construction industry, it should be discouraged in firms with the harvester strategy. This is because the results suggest that staff participation in decision-making is detrimental to the performance of firms with the harvester strategy, however, in line with the findings of Arthur $(1992,1994)$ and Huselid (1995), it enhances the performance of firms with the selective, prestige and sustenance strategies. This probably suggests that the contributions of staff may be necessary when an architectural firm competes by specialization, prestige or simply industry tradition. However, such contributions may constitute a draw-back for firms where the main objective is to explore and pursue and a chance for staff contribution may slow the process down or abort the process completely. A high number of non-architecture professionals increased the performance of firms which competed using broad actions based on established industry tradition (sustenance strategy) but was detrimental to the performance of firms with the harvester, selective and prestige strategies.

Worthy of note is the fact that the effect of the influence of the interaction of business strategy with the workforce on performance of the firms was higher than the direct influence of business

Oluwatayo, A A and Amole, D (2011) 'Architectural firms: workforce, business strategy and performance', Australasian Journal of Construction Economics and Building, 11 (4) 21-44 
strategy. This probably confirms the assertion by Hitt et al (2001) that without considering the workforce in the implementation of strategy, the result may be failure. It is interesting to note that although information technology (IT) has been identified as a resource in literature (Bharadwaj, 2000); the use of IT as a staff selection criterion (in this context AUTOCAD and IT literacy) was not significantly related to the performance of the firms. In addition, flexibility in terms of the staff being allowed to express personal styles and initiatives was also not significantly related to the performance of the firms. It thus appears that skill flexibility, either in terms of the importance of IT in the selection of staff or possession of non-architecture qualification by the principal did not contribute in any way to the performance of the firms. The staffing techniques and the means of compensation of staff did not influence the performance of the firms. This probably suggests that although the influence may be indirect, the context is not related to the business strategy of the firms.

The findings confirm the conceptual model of the study. The conceptual model first suggested a direct influence of the workforce on the performance of the firms. This study found that the workforce directly influence $28 \%$ of the variance in performance of the firms. The conceptual model also suggested that business strategy may influence performance directly, and in addition interact with workforce to further influence performance. The study found that there was a direct influence of the business strategy is not so high (accounting for resulting in $1.4 \%$ of the variance in performance), when in interaction with workforce, the influence of workforce on performance was further increased by $9 \%$.

\section{Conclusion}

The study aimed at investigating the effect of workforce and strategy on performance of architectural firms. The results show that the workforce of architectural firms is indeed a resource explaining $28 \%$ of the variance in the profitability of the firms. The resource-based view suggest that human resources should be integrated into the formulation of strategy. The use of the resource-based view in examining the potential of the workforce of architectural firms in implementing the business strategy of the firms thus proved useful in this study. This is because the results show that the right workforce with the right workforce characteristics and human resource practice led to a further improvement of $9 \%$ in performance. This findings support recent arguments on the impact of workforce on performance. This study thus provides empirical support for the values of firm workforce resources and the use of the workforce in the implementation of business strategy. This is because, in line with the conceptual model, the findings of the study suggest that there is indeed a direct influence of the workforce on the performance of the firms and an additional impact on the performance of the firms from the interaction of the workforce with business strategy.

One implication of these findings is that it adds consistent empirical support for the significant influence of the workforce as a resource on the performance of firms, suggesting that the resource-based view of human resources is credible. Thus, architectural firms should view their workforce as a resource and an asset, which should be invested in. This is in view of their immense contribution to the firms' profitability. The professional body also needs to set standards of experience required of aspiring principal partners to improve the outlook of the profession in terms of performance. In addition, the results suggest that the employment of nonarchitecture professionals may be absolutely unnecessary except when the firm is adopting a sustenance strategy. In terms of the management of the workforce, an implication of the findings is that architectural firms need to be more liberal in permitting staff participation in decision making if they are to be more profitable, except they are adopting the harvester strategy.

Oluwatayo, A A and Amole, D (2011) 'Architectural firms: workforce, business strategy and performance', Australasian Journal of Construction Economics and Building, 11 (4) 21-44 
A major limitation in this study was the unavailability of data to measure profitability. However, since the study by Wall et al, (2004) shows that the perception of managers were as valid as the objective measures, it is believed that the results of this study are also valid. Future research may however consider more objective measures of profitability. There is need for further research to better understand the reasons for the outcomes. The study only examined crosssectional performance differences between architectural firms. To gain a clearer understanding, future research should consider longitudinal studies. Since a firm is a complex of many strategies, there may be other strategies which moderate the relationship between workforce and performance. Future studies may consider the influence of other strategies. The fit between the workforce characteristics, workforce management and performance may also be considered in further studies. In addition, other resources of the professional service firm need to be studied to understand their contributions to the performance of the firms. The study of other dimensions of performance is also necessary to understand how they also vary with workforce and strategy. The moderating effects of other contexts such as technology and structure may also be studied in order to gain further insight into the workforce- performance relationship.

\section{References}

Acedo, F. J., Barroso C. and Galan J. L. (2006) 'The resource-based theory: dissemination and main trends', Strategic Management Journal 27, 621-636

Alvesson, M. (1995) Management of Knowledge-Intensive Companies. De Gruyter: Berlin/New York

Arthur, J. B. (1992) 'The Link between business strategy and industrial relations systems in American steel mini-mills', Industrial and Labor Relations Review, 45, 488-506

Arthur, J. B. (1994) 'Effects of human resource systems on manufacturing performance and turn-over', Academy of Management Journal, 37, 670-687

Bainey, J.B and Hesterly, W. (1999) 'Organizational economics: understanding the relationship between organization and economic analysis in Clegg, S. R. and Hardy, C., Studying Organizations: Theory and Method, Sage Publications, London, 109-141

Barney, J. (1991) 'Firm resources and sustained competitive advantage', Journal of Management, 17, 99-120

Becker B. and Gerhart (1996) 'The impact of human resource management on organizational performance: progress and prospects', The Academy of Management Journal 39 (4), 779-801

Becker, W. M., M. F., Herman, P. A., Samuelson, A. P. and Webb (2001) 'Lawyers get down to business' McKinsey Quarterly, 2, 4-55

Bharadwaj A. S. (2000) 'A resource-based perspective on information technology capability and firm performance: an empirical investigation', MIS Quarterly, 24 (1), 169-196

Blau, J. (1984) 'Architecture and Daedalean Risk', Architects and Firms: a Sociological Perspective on Architectural Practice, MIT Press, 133-145

Brock, David M., Yaffe Tal and Dembovsky Mark (2006) 'The global law firm: an initial study of strategy and performance', International Journal of Business and Economics, 5 (2), 161-172

Brown A. D., Kornberger M., Clegg S. R. and Carter C. (2010) 'Invisible walls and silent hierarchies: a case study of power relations in an architecture firm', Human Relations, 63, 525550

Carton R. B. and Hofer, C. W. (2006) Measuring Organizational Performance: Metrics for Entrepreneurship and Strategic Management Research Edward Elgar Publishing Limited

Oluwatayo, A A and Amole, D (2011) 'Architectural firms: workforce, business strategy and performance', Australasian Journal of Construction Economics and Building, 11 (4) 21-44 
UKChan T. K. (2009) 'Measuring performance of the Malaysian construction industry', Construction Management and Economics 27 (12), 1231 - 1244

Cheah, C. Y. J., Kang J. and Chew D. A. S. (2007) 'Strategic analysis of large local construction firms in China', Construction Management and Economics, 25 (1), 25 - 38

Cliff, P. D., Jennings, J. E., and Greenwood R. (2006) 'The strategic positioning of professional service firm start-ups: Balance beguiles but purism pays', In R. Greenwood, R. Suddaby, eds. Research in the Sociology of Organizations, Vol. 24

Collis, D. J. (1994) 'Research note: How valuable are organisational capabilities', Strategic Management Journal, 15, 143-152

Conant, J.S.; Mokwa, M. P and Varadarajan P. R (1990) 'Strategic types, distinctive marketing competencies and organizational performance: A multiple measures-based study', Strategic Management Journal

Daily, C. M., Certo, S. T. and Dalton, D. R. (2000) 'A decade of corporate women: Some progress in the board- room, none in the executive suite', Strategic Management Journal, 20, 93-99

David, R. J. (2001) 'A narrow target or a wide net? Specialist and generalist strategies in the management consulting industry', Best Paper Award, Proceedings of Administrative Sciences Association of Canada Annual Meetings, London Ontario, 13-23

Deephouse, D. L. (2000) 'Media reputation as a strategic resource: An integration of mass communications and resource based theories', Journal of Management 26 (6), 1091-1112

DeSarbo, W. S., Di, B. C., Anthony, S. M., and Sinha I. (2005) 'Revisiting the miles and snow strategic framework: uncovering relationships between strategic types, capabilities, environmental uncertainty, and firm performance', Strategic Management Journal, 26 (1), 47-74

Dess, G. G. and Robinson R. B. (1984) 'Measuring organizational performance in the absence of objective measures: The case of the privately-held firm and conglomerate business unit', Strategic Management Journal 5 (3), 265-273

Dewan, S. and Kraemer K. L. (2000) 'Information technology and productivity: Evidence from country- level data', Management Service, 46 (4), 548-62

Druker J. and Croucher R. (2000) 'National collective bargaining and employment flexibility in the European building and civil engineering industries', Construction Management and Economics 18 (6), 699 - 709

Ettinger, E. (2008) Highly Effective Behavior of Financial Consultants, Betriebswirtschaftlicher: Verlag Gabler, 31-37

Flamholtz, E. and Lacey, J. (1981) Personnel Management: Human Capital Theory and Human Resources Accounting, Los Angeles, CA, Institute of Industrial Relations, UCLA

Fraser C. (2000) 'The influence of personal characteristics on effectiveness of construction site managers', Construction Management and Economics 18 (1), 29 - 36

Frankfort-Nachmias, C. and Nachmias, D. (1992) Research Methods in the Social Sciences, Worth Pub

Ganesan, S. (1994) 'Employment maximization in construction in developing countries', Construction Management and Economics, 12 (4), 323-335

Ginsberg, A., (1994) 'Minding the competition: from mapping to mastery', Strategic Management Journal, 15, 153-174

Oluwatayo, A A and Amole, D (2011) 'Architectural firms: workforce, business strategy and performance', Australasian Journal of Construction Economics and Building, 11 (4) 21-44 
Grant, Robert M. (1991) 'The resource-based theory of competitive advantage: Implications for strategy formulation', California Management Review, 33, 114-135

Greenwood, R., Li, S. X., Prakash, R. and Deephouse, D. L. (2005) 'Reputation, diversification, and organizational explanations of performance in professional service firms', Organization Science, 16 (6), 661-673

Hansen, G.S. and Wernerfelt, B. (1989) 'Determinant of firms performance: relative importance economic and organizational factors', Strategic Management Journal, 10, 399- 411

Hitt, M. A., Bierman, L., Shimizu, K. and Kochhar R. (2001) 'Direct and moderating effects of human capital on strategy and performance in professional service firms: a resource-based perspective', The Academy of Management Journal, 44 (1), 13-28

Hofer, C. W. and Dan S. (1978) Strategy Formulation: Analytical Concepts. St. Paul, MN: West Publishing Co.

Huselid, M. (1995) 'The impact of human resource management practices on turnover, productivity, and corporate financial performance', Academy of Management Journal, 38, 635672

Ichniowski, C., Shaw, K., and Prennushi, G. (1994) The Effects of Human Resource Management Practices on Productivity, Working paper, Columbia University Graduate School of Business, New York

Jayawardane A. K. W. and Gunawardena N. D. (1998) 'Construction workers in developing countries: a case study of Sri Lanka', Construction Management and Economics, 16 (5), 521 530

Jones, C. and Lichtenstein B. (2000) 'The 'Architecture' of careers: How career competencies reveal firm dominant logic in professional services', in M. Peiperl, M. Arthur, R. Goffee, and T. Morris (Eds.), Career Frontiers, New York, NY, Oxford University Press, 153-176

Jones, C., Hesterley W. S., Fladmoe-Lindquist, K and Borgatti, S. P. (1998) 'Professional constellation: how strategies and capabilities influence collaborative stability and change', Organizational Science, 9 (3), 396-410

Kärreman, D., S. Sveningsson, M. and Alvesson. (2002) 'The return of the machine bureaucracy? Management control in the work settings of professionals', International Study of Management Organizations, 32 (2), 70-92

Katsanis C. J. and Katsanis L. P., (2001) 'An examination of business activities and implications for marketing in the architectural, engineering and construction (AEC) Industry', in Susanne Wilkinson, International Journal for Construction Marketing, 3 (1), 33-52

Kim A. and Arditi D. (2010) 'Performance of minority firms providing construction management services in the US transportation sector', Construction Management and Economics, 28 (8), 839 $-851$

Kleiner, M. M., Block, R. N., Roomkin, M. and Salsburg, S. W. (1987) Human Resources and the Performance of the Firm, University of Wisconsin, Madison, WI

Lado A. A. and Wilson M. C. (1994) Human resources systems and sustained competitive advantage: a competency-based perspective

Larsen, T. (2005) Minding Your Ps: Three Fundamentals for Improving Business Performance in AIA Practice Management Digest. Available at http://www.aia.org/nwsltr pm.cfm Accessed 16-08-06 
Lee, J. and Miller, D. (1999) 'People matter: Commitment to employees, strategy and performance in Korean firms', Strategic Management Journal, 20, 579-503

Li, H., Li, V., Skitmore, M, Wong J. K. W. and Cheng E. W. L. (2009) 'Competitiveness factors: A study of real estate market in China', Construction Management and Economics, 27 (6), 567 579

Lieberman, M. and Montgomery, D. (1998) 'First-mover (Dis) advantages: Retrospective and link with resource-based view', Strategic Management Journal, 19 (12)

Lowendahl, B. (2000) Strategic Management of Professional Firms, 2nd ed, Handelshojskolens Forlag, Copenhagen

Lu, S. L. and Sexton, M. (2006) Innovation in Small Construction Knowledge-Intensive Professional Service Firms. RICS Research Paper Series 6:14 Available at http://www.rics.org/site/download feed.aspx?filelD=3035\&fileExtension=PDF Accessed 22-1111

Luu, D., Kim, T., Cao S. H. and Park, Y. (2008) 'Performance measurement of construction firms in developing countries' Construction Management and Economics, 26 (4), 373 - 386

MacDuffie, J. P. (1995) 'Human resource bundles and manufacturing performance: Organizational logic and flexible production systems in the world auto industry', Industrial and Labor Relations Review, 48, 197-221

Malhotra, N. T., Morris, C. R. and Hinings (2006) 'Variations in organizational form among professional service organizations', in Greenwood R., and Suddaby R., eds., Research in the Sociology of Organizations: Professional Service Firms, Vol. 26. Elsevier, Amsterdam, The Netherlands

Miles, R. E. and Snow, C.C. (1978) Organizational Strategy, Structure and Process, New York, McGraw-Hill

Miller, D. and Shamsie, J. (1996) The resource-based view of the firm in two environments: The Hollywood film studios from 1936-1965, Academy Management Journal, 39, 19-543

National Bureau of Statistics (2009) Annual Abstract of Statistics, Federal Republic of Nigeria

Ness, K. (2010) 'The discourse of 'Respect for People' in UK construction', Construction Management and Economics, 28 (5), 481 - 493

Oliver, C. (1997) 'Sustainable competitive advantage: Combining institutional and resource based View', Strategic Management Journal, 18, 697-713

Parnell, J. A. and Wright P. (1993) 'Generic strategy and performance: an empirical test of miles and snow typology', British Journal of Management, 4 (1), 29-36

Parnell, J. A., Carraher, S. and Odom, R. (2000) 'Strategy and performance in the entrepreneurial computer software industry', Journal of Business and Entrepreneurship, 49-66

Patterson, M.G., West, M.A., Lawton, R. and Nickell, J. (1997) 'Impact of people management practices on business performance', Issues in People Management, Vol. 22. London: Institute of Personnel and Development

Pennings J. M. Lee, K. and Wiitteloostuijn A. (1998) 'Human capital, social capital and firm dissolution', Academy of Management Journal, 41, 425-440

Phua, F. T. T. (2006) 'Predicting construction firm performance: an empirical assessment of the differential impact between industry- and firm-specific factors', Construction Management and Economics, 24 (3), 309 - 320 
Raiden, A. B., Dainty, A. R. J. and Neale, R. H. (2008) 'Understanding employee resourcing in construction organizations', Construction Management and Economics, 26 (11), 1133 - 1143

Rameezdeen, R. and Ramachandra T. (2008) 'Construction linkages in a developing economy: the case of Sri Lanka', Construction Management and Economics, 26 (5), 499-506

Register of Architectural Firms entitled to practice in the federal republic of Nigeria, 2006 edition Reich, R. B. (1991) The Work of Nations, New York: Vintage Books

Richard, O. C. (2000) 'Racial Diversity, business strategy and firm performance: a resourcebased view', The Academy of Management Journal, 43 (2), 164-177

Rose, R. C. and Kumar, N. (2006) 'The influence of organizational and human resource management strategies on performance', Performance Improvement, Interscience Wiley, USA

Russell, J. S., Terborg, J. R., and Powers, M. L. (1985) 'Organizational productivity and organizational level training and support', Personnel Psychology, 38, 849-863

Sabourin, V. and Pinsonneault, I. (1997) 'Strategic formation of competitive high technology clusters', International Journal of Technology Management, 13 (2), 165-178

Sagada, M. L. (2002) 'Architectural education and practice in Nigeria: Reflections on the contemporary situation', Association of Architectural Educators in Nigeria (AARCHES) Journal, 2 (1), $21-25$

Schwennsen K. (2004) Firm Planning and Positioning, lowa State University, Department of Architecture, Available at

http://www.lib.iastate.edu/commons/arch482/04spr/pdf/JFirmPlan\&Position.pdf Accessed 13-09$\underline{06}$

Sherer, P. D. (1995) 'Leveraging human assets in law firms: Human capital structures and organizational capabilities', Industrial and Labor Relations Review, 48, 671- 691

Terpstra, D. E. and Rozell, E. J. (1993) 'The relationship of staffing practices to organizational level measures of performance', Personnel Psychology, 46, 27-48

U.S. Department of Labor (1993) High Performance Work Practices and Firm Performance, Washington, DC: U.S. Government Printing Office

Ulrich, D. and Lake, D. (1991) 'Organizational capability: Creating competitive advantage', Academy of Management Executive, 5 (1), 77-92

Wall T. D., Michie, J., Patterson, M., Wood, S. J., Sheehan, M., Clegg, C. W. and Wwest, M. (2004) 'On the validity of subjective measures of company performance', Personnel Psychology, 57 (1), 95-118

Wang, G. and Yang J., (2000) 'Business strategy and Australian construction industry', International Journal for Construction Marketing, 2 (1)

Wernerfelt, B. (1984) 'A resource-based view of the firm', Strategic Management Journal, 5, 171-180

White B. (2005) RIBA Constructive Change: A Strategic Industry Study into the Future of the Architects' Profession, Full Report. Available at http://www.architecture.com/fileLibrary/pdf/Constructive Change Report - Full (Final).pdf

Accessed 17-08-06

Wright, P. M. and McMahan, G. C. (1992) 'Theoretical perspectives for strategic human resource management', Journal of Management, 18 (2) 295-320 
Wright, P. M., McMahan, G. C., and McWilliams, A. (1993) 'Human resources and sustained competitive advantage: a resource-based perspective', International Journal of Human Resources Management, 5, 301-326

Xia, B., Chan, A. P. C. and Yeung, J. F. Y. (2009) 'Identification of key competences of designbuilders I the construction market of the People's Republic of China (PRC)', Construction Management and Economics, 27 (11), 1141-1152

Youndt, Mark A., Snell, Scott A., Dean, James W. Jr. and Lepak, David P. (1996) 'Human resource management, manufacturing strategy, and firm performance', The Academy of Management Journal, 39 (4), 836-866

\section{Appendix 1: Factors (workforce characteristics and human resource management)}

\begin{tabular}{|c|c|c|}
\hline Factors & Variables & $\begin{array}{l}\text { Component } \\
\text { Loading }\end{array}$ \\
\hline \multirow{17}{*}{$\begin{array}{l}\text { Architects and work } \\
\text { structure }\end{array}$} & existence of departments and work units & -.612 \\
\hline & total number of staff & .877 \\
\hline & number of architects & .744 \\
\hline & number of administrative staff & .709 \\
\hline & architects with OND/HND & .652 \\
\hline & architects with BArch/MSc & .689 \\
\hline & architects who are partners & .632 \\
\hline & architects who are senior architects & .508 \\
\hline & architects who are junior architects & .662 \\
\hline & architects who are trainee architect & .633 \\
\hline & architects with other designation & .572 \\
\hline & number of male architects & .705 \\
\hline & number of female architects & .612 \\
\hline & number of male other professionals & .601 \\
\hline & number of female other professionals & .660 \\
\hline & number of male admin staff & .702 \\
\hline & number of female admin staff & .553 \\
\hline \multirow{4}{*}{$\begin{array}{l}\text { Number of non-architecture } \\
\text { professionals }\end{array}$} & number of quantity surveyors & .715 \\
\hline & number of builders & .717 \\
\hline & number of accountants & .712 \\
\hline & personnel with other qualification & .536 \\
\hline \multirow{2}{*}{$\begin{array}{l}\text { Staff participation in } \\
\text { decision making }\end{array}$} & degree of centralization & .500 \\
\hline & centralization of decision on managing projects & .535 \\
\hline \multirow[t]{4}{*}{ Skill flexibility } & number of other staff & .519 \\
\hline & $\begin{array}{l}\text { encouragement of staff expression of personal } \\
\text { styles and initiatives }\end{array}$ & -.611 \\
\hline & other qualification(s) of principal & .543 \\
\hline & $\begin{array}{l}\text { importance of AUTOCAD/IT literacy in the } \\
\text { selection of new staff }\end{array}$ & .572 \\
\hline \multirow{3}{*}{$\begin{array}{l}\text { Age and experience of } \\
\text { principal }\end{array}$} & architects with MNIA/FNIA & -.540 \\
\hline & age group of the principal partner & -.504 \\
\hline & $\begin{array}{l}\text { number of years of registration of principal } \\
\text { architect }\end{array}$ & .565 \\
\hline
\end{tabular}

Oluwatayo, A A and Amole, D (2011) 'Architectural firms: workforce, business strategy and performance', Australasian Journal of Construction Economics and Building, 11 (4) 21-44 


\section{Appendix 2: Principal component loadings (workforce characteristics and human resource management)}

\begin{tabular}{|c|c|c|c|c|c|}
\hline & \multicolumn{5}{|c|}{ Dimension } \\
\hline & 1 & 2 & 3 & 4 & 5 \\
\hline existence of departments and work units & -.612 & .004 & .028 & .016 & -.126 \\
\hline total number of staff & .877 & -.065 & .187 & -.083 & -.021 \\
\hline number of architects & .744 & -.313 & .019 & -.279 & -.317 \\
\hline number of administrative staff & .709 & -.070 & .146 & -.285 & -.225 \\
\hline architects with OND/HND & .652 & .101 & -.334 & -.028 & .203 \\
\hline architects with BArch/MSc & .689 & -.314 & .081 & .023 & -.462 \\
\hline architects who are partners & .632 & -.031 & -.032 & -.004 & -.169 \\
\hline architects who are senior architects & .508 & -.346 & .099 & -.295 & -.218 \\
\hline architects who are junior architects & .662 & -.356 & .067 & -.161 & -.097 \\
\hline architects who are trainee architect & .633 & .100 & .008 & .205 & -.047 \\
\hline architects with other designation & .572 & -.197 & .131 & .296 & .483 \\
\hline number of male architects & .705 & -.114 & -.061 & -.155 & -.289 \\
\hline number of female architects & .612 & -.313 & -.172 & -.301 & .035 \\
\hline number of male other professionals & .601 & .202 & -.025 & .217 & .344 \\
\hline number of female other professionals & .660 & -.351 & .199 & .128 & .306 \\
\hline number of male admin staff & .702 & .124 & .039 & .181 & -.048 \\
\hline number of female admin staff & .553 & .018 & .044 & .192 & -.142 \\
\hline number of quantity surveyors & .294 & .715 & .431 & -.207 & -.107 \\
\hline number of builders & .280 & .717 & .431 & -.211 & -.115 \\
\hline number of accountants & .310 & .712 & .424 & -.208 & -.109 \\
\hline personnel with other qualification & .215 & .536 & .304 & -.088 & .019 \\
\hline degree of centralization & .448 & .398 & .500 & -.181 & -.102 \\
\hline centralization of decision on managing projects & .350 & .402 & .535 & -.212 & -.059 \\
\hline range of number of other staff & .416 & .312 & .366 & .519 & .133 \\
\hline $\begin{array}{l}\text { encouragement of staff expression of personal styles } \\
\text { and initiatives }\end{array}$ & -.176 & .131 & -.290 & -.611 & -.243 \\
\hline other qualification(s) of principal & .217 & .095 & -.007 & .543 & -.008 \\
\hline $\begin{array}{l}\text { importance of AUTOCAD/IT literacy in the selection of } \\
\text { new staff }\end{array}$ & .122 & .023 & .136 & .572 & .369 \\
\hline architects with MNIA/FNIA & .435 & .026 & .026 & .243 & -.540 \\
\hline age group of the principal partner & .116 & -.239 & .012 & .485 & -.504 \\
\hline number of years of registration of principal architect & -.114 & .330 & -.141 & -.281 & .565 \\
\hline importance of teamwork and staff development & .127 & .383 & -.415 & -.060 & .158 \\
\hline driving employees to achieve result & -.007 & .105 & -.403 & -.112 & .301 \\
\hline gender equity in staff hiring & -.045 & .027 & -.432 & -.269 & .010 \\
\hline gender equity in job allocation & -.119 & .105 & -.365 & .214 & -.241 \\
\hline $\begin{array}{l}\text { highest qualification of the principal architect in } \\
\text { architecture }\end{array}$ & .209 & -.406 & .237 & .063 & -.337 \\
\hline number of firms the principal have worked previously & .026 & .146 & -.167 & -.047 & -.385 \\
\hline leadership style of principal & -.235 & -.001 & .147 & -.137 & -.043 \\
\hline $\begin{array}{l}\text { importance of design competence in the selection of } \\
\text { new staff }\end{array}$ & .181 & .223 & -.154 & .031 & .231 \\
\hline $\begin{array}{l}\text { importance of knowledge of construction in the selection } \\
\text { of new staff }\end{array}$ & -.295 & -.006 & .420 & .093 & .286 \\
\hline importance of gender in the selection of new staff & .347 & -.165 & .076 & -.145 & .383 \\
\hline importance of personality in the selection of new staff & .269 & -.374 & .156 & -.402 & .175 \\
\hline $\begin{array}{l}\text { importance of educational qualification in the selection } \\
\text { of new staff }\end{array}$ & .444 & -.184 & .019 & .064 & .336 \\
\hline
\end{tabular}

Oluwatayo, A A and Amole, D (2011) 'Architectural firms: workforce, business strategy and performance', Australasian Journal of Construction Economics and Building, 11 (4) 21-44 


\begin{tabular}{|c|c|c|c|c|c|}
\hline & \multicolumn{5}{|c|}{ Dimension } \\
\hline & 1 & 2 & 3 & 4 & 5 \\
\hline $\begin{array}{l}\text { importance of interpersonal/ managerial skills in the } \\
\text { selection of new staff }\end{array}$ & .368 & -.233 & .171 & .115 & .375 \\
\hline importance of other factors in the selection of new staff & .023 & .103 & -.058 & .027 & .038 \\
\hline staff retention through improved salary & -.013 & .068 & -.141 & .106 & -.079 \\
\hline staff retention through retention bonus & -.072 & .089 & .085 & .179 & .085 \\
\hline staff retention through performance bonus & -.177 & -.095 & .411 & .106 & -.099 \\
\hline staff retention through rewards and recognitions & -.354 & -.055 & .168 & .193 & .145 \\
\hline staff retention staff development & -.104 & -.340 & .154 & .196 & .028 \\
\hline staff retention through leadership development & -.010 & .006 & .140 & -.167 & .338 \\
\hline staff retention through other means & .032 & -.046 & -.053 & -.108 & -.126 \\
\hline staff organization for each project & -.318 & .097 & -.075 & -.305 & -.155 \\
\hline specialization of public/clients relations task & -.476 & -.040 & .208 & .393 & -.045 \\
\hline specialization of personnel management task & -.235 & -.204 & -.092 & .094 & .212 \\
\hline specialization of working drawing task & -.192 & -.256 & .304 & .202 & -.115 \\
\hline specialization of sourcing for jobs task & -.249 & -.053 & .265 & -.295 & -.024 \\
\hline specialization of maintenance task & -.498 & .101 & .239 & -.044 & -.040 \\
\hline specialization of accounts task & -.475 & .097 & -.118 & .181 & -.115 \\
\hline specialization of transport task & -.111 & -.196 & .205 & -.104 & -.106 \\
\hline specialization of training task & .098 & .061 & .047 & .235 & -.150 \\
\hline specialization of design task & -.305 & -.140 & .221 & .328 & -.105 \\
\hline specialization of modeling task & .117 & .042 & -.043 & .083 & -.254 \\
\hline specialization of site meeting task & -.449 & .112 & .390 & .238 & .074 \\
\hline specialization of welfare task & -.256 & -.139 & .456 & .043 & .020 \\
\hline $\begin{array}{l}\text { centralization of decision on how to get new jobs and } \\
\text { clients }\end{array}$ & .030 & .182 & -.416 & .108 & -.109 \\
\hline $\begin{array}{l}\text { centralization of decision on collaborations with other } \\
\text { firms }\end{array}$ & .015 & .272 & .085 & .370 & -.058 \\
\hline $\begin{array}{l}\text { centralization of decision on managing the non-design } \\
\text { staff }\end{array}$ & .284 & .354 & -.297 & .183 & .002 \\
\hline $\begin{array}{l}\text { centralization of decision on fees to be charged for } \\
\text { projects }\end{array}$ & .442 & -.250 & .190 & .203 & .396 \\
\hline $\begin{array}{l}\text { centralization of decision on design ideas to use for } \\
\text { projects }\end{array}$ & .190 & .266 & -.248 & -.091 & .105 \\
\hline number of professionals & .320 & .383 & -.487 & -.019 & -.098 \\
\hline centralization of decision on salaries of staff & .477 & .312 & -.281 & .240 & .091 \\
\hline number of urban planners & .253 & .368 & -.148 & .268 & .027 \\
\hline number of architects with BSc & .206 & -.259 & .036 & -.320 & .324 \\
\hline number of architects PhD & .336 & -.394 & .164 & -.388 & .297 \\
\hline number of architects MBA & .332 & .054 & -.281 & -.040 & -.090 \\
\hline years of experience before stating a firm & -.009 & .282 & -.433 & .122 & -.126 \\
\hline years of experience of principal & .038 & -.317 & .187 & .291 & -.458 \\
\hline number of engineers & -.494 & -.137 & .472 & -.372 & -.002 \\
\hline
\end{tabular}

Oluwatayo, A A and Amole, D (2011) 'Architectural firms: workforce, business strategy and performance', Australasian Journal of Construction Economics and Building, 11 (4) 21-44 